Int. J. Dev. Biol. 57: 383-389 (2013)

doi: $10.1387 / \mathrm{ijdb} .130058 \mathrm{ma}$

\title{
Induction of intermediate mesoderm by retinoic acid receptor signaling from differentiating mouse embryonic stem cells
}

\author{
SHIHO OEDA ${ }^{1}$, YOHEI HAYASHI ${ }^{1}$, TECHUAN CHAN ${ }^{1}$, MINORU TAKASATO ${ }^{1}$, YUKO AIHARA ${ }^{1}$, \\ KOJI OKABAYASHI ${ }^{1}$, KIYOSHI OHNUMA ${ }^{1}$ and MAKOTO ASASHIMA*,1,2 \\ ${ }^{1}$ Department of Life Sciences (Biology), Graduate School of Arts and Sciences, The University of Tokyo and \\ ${ }^{2}$ Research Center for Stem Cell Engineering, National Institute of Advanced Industrial Science and Technology (AIST), \\ Tsukuba, Japan.
}

\begin{abstract}
Renal lineages including kidney are derived from intermediate mesoderm, which are differentiated from a subset of caudal undifferentiated mesoderm. The inductive mechanisms of mammalian intermediate mesoderm and renal lineages are still poorly understood. Mouse embryonic stem cells (mESCs) can be a good in vitro model to reconstitute the developmental pathway of renal lineages and to analyze the mechanisms of the sequential differentiation. We examined the effects of Activin $A$ and retinoic acid (RA) on the induction of intermediate mesoderm from $m E S C s$ under defined, serum-free, adherent, monolayer culture conditions. We measured the expression level of intermediate mesodermal marker genes and examined the developmental potential of the differentiated cells into kidney using an ex vivo transplantation assay. Adding Activin A followed by RA to mESC cultures induced the expression of marker genes and proteins for intermediate mesoderm, odd-skipped related 1 (Osr1) and Wilm's Tumor 1 (Wt1). These differentiated cells integrated into laminin-positive tubular cells and Pax2-positive renal cells in cultured embryonic kidney explants. We demonstrated that intermediate mesodermal marker expression was also induced by $R A$ receptor (RAR) agonist, but not by retinoid $X$ receptor (RXR) agonists. Furthermore, the expression of these markers was decreased by RAR antagonists. We directed the differentiation of mESCs into intermediate mesoderm using Activin A and RA and revealed the role of RAR signaling in this differentiation. These methods and findings will improve our understanding of renal lineage development and could contribute to the regenerative medicine of kidney.
\end{abstract}

KEY WORDS: kidney, Activin A, odd-skipped related 1, Pax 2, Wilm's tumor 1

Introduction

Mammalian pluripotent stem cells (PSCs) including embryonic stem cells (ESCs) (Evans and Kaufman, 1981; Martin, 1981) and induced pluripotent stem cells (iPSCs) (Takahashi et al., 2007; Takahashi and Yamanaka, 2006) can differentiate into three germ layers. Number of studies demonstrated to differentiate into specific cell lineages from PSCs by cytokines and chemicals and provided useful insights into the molecular mechanisms of mammalian development in vitro and for future regenerative medicine. As to renal lineages, although several independent studies have been demonstrated to differentiate into these lineages from mouse ESCs (mESCs) (Bruce et al., 2007; Vigneau et al., 2007), directed differentiation methods into renal lineages have never been reported (Nishinakamura, 2008). Renal lineages are derived from intermedi- ate mesoderm, which are differentiated from a subset of caudal primitive mesoderm (Dressler, 2009; Reidy and Rosenblum, 2009). To achieve directed differentiation into renal lineages, step-wise differentiation system through intermediate mesoderm is required.

We previously reported that treatment with Activin A and retinoic acid (RA) induces renal lineages from amphibian undifferentiated PSCs (Moriya et al., 1993; Osafune et al., 2002; Uochi and Asashima, 1996). As for the role of Activin A, it induces broad mesoendodermal derivatives from amphibian undifferentiated PSCs in vitro (Asashima et al., 1990; Asashima et al., 1991; Kaneko et al.,

\footnotetext{
Abbreviations used in this paper: iPSC, induced pluripotent stem cell; mESG, mouse embryonic stem cell; PSC, pluripotent stem cell; RA, retinoic acid; RAR, retinoic acid receptor; $\mathrm{RXR}$, retinoid $\mathrm{X}$ receptor.
}

*Address correspondence to: Makoto Asashima.Tsukuba Central 4, 1-1-1 Higashi, Tsukuba, Ibaraki 305-8562, Japan.
Tel: +81-29-861-2529. Fax: +81-29-861-2897. E-mail: asashi@ bio.c.u-tokyo.ac.jp 
2008; Okabayashi and Asashima, 2003). As for the role of RA, it does not display any inducing activity in the amphibian differentiation assays, but it can modify the action of Activin A on mesoderm pattern formation in concentration- and time- dependent manners (Ariizumi and Asashima, 2001; Fukui and Asashima, 1994). In mammalian development, number of studies demonstrated that Activin-related genes have important functions in mesoderm formation and differentiation using mice deficient in these genes (Goumans and Mummery, 2000; Schier and Shen, 2000). Mice deficient in RA-related genes impair various tissue development including renal lineages (Duester, 2008). From these findings, we hypothesized that the sequential addition of Activin A and RA could induce renal lineages from mammalian PSCs.

In this study, we aimed to differentiate mESCs into renal lineages using defined culture conditions and dissect the inductive signal pathways for intermediate mesoderm differentiation. We previously developed chemically-defined, serum-free culture system for mESCs (Furue et al., 2005). This culture system enables us to analyze the direct effects of various cytokines including extracellular matrix (ECM) proteins (Hayashi et al., 2007), Wnt

A

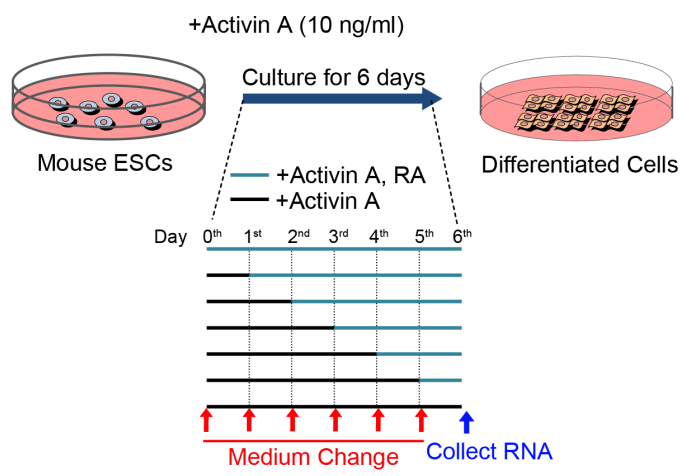

B

Osr1 Expression

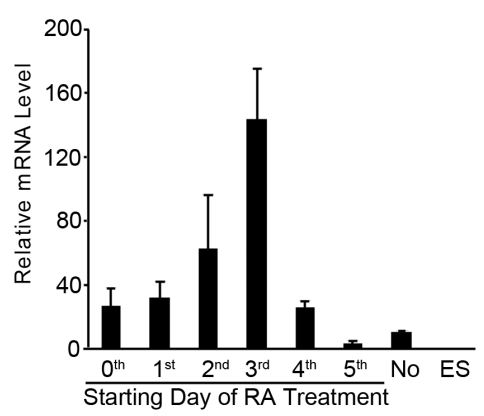

D

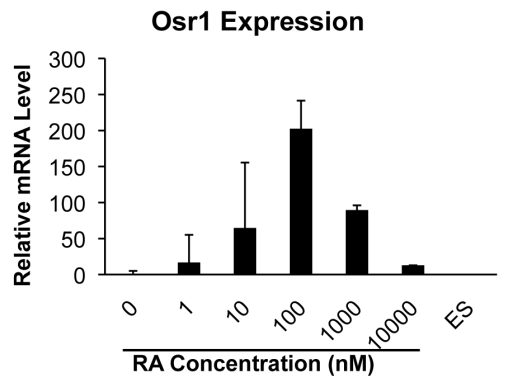

C

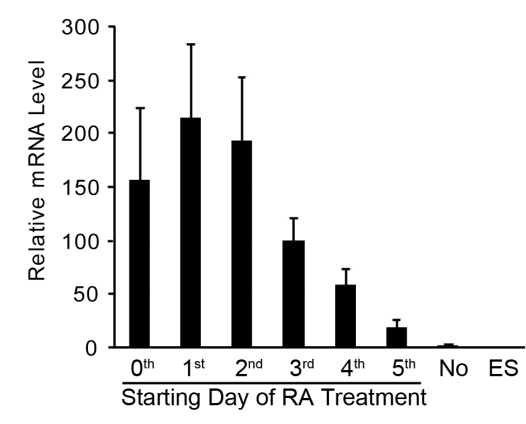

E

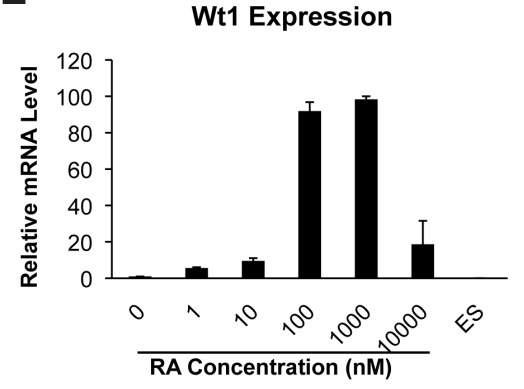

proteins (Nakanishi et al., 2009), bone morphogenetic proteins (BMP) (Hayashi et al., 2010b), and fibroblast growth factor (FGF) (Aihara et al., 2010). In this culture system, we used Activin A and $\mathrm{RA}$ as the candidates of inducer to differentiate mESCs into renal lineage and examined the expression levels of the intermediate mesodermal marker genes in these cells. We characterized that these differentiated cells can integrated into developing kidney explant cultures. Furthermore, we used RAR agonists and antagonists to examine the involvement of RAR signaling in intermediate mesodermal differentiation from mESCs.

\section{Results}

\section{Induction of intermediate mesodermal gene expression by RA combined with Activin A}

We first asked whether RA together with Activin A induced intermediate mesoderm from mESCs. Undifferentiated mESCs were seeded in the defined medium supplemented with $10 \mathrm{ng} / \mathrm{ml}$ of Activin A on laminin-coated dishes $\left(2 \mu \mathrm{g} / \mathrm{cm}^{2}\right)$ at $0^{\text {th }}$ day. From $0^{\text {th }}$ to $5^{\text {th }}$ day, $100 \mathrm{nM}$ of RA was added in the culture medium; i.e., RA and Activin A was treated for 6, 5, 4, 3, 2, 1 days. No addition of RA was used as a control condition. Culture medium was changed every day. The differentiated cells were collected on day 6 (Fig. 1A) and assayed by quantitative RT-PCR for the gene expression of intermediate mesoderm markers, odd-skipped related 1 (Osr1) and Wilm's tumor 1 (Wt1). Osr1 is expressed in intermediate mesoderm in developing mouse embryos (Wang et al., 2005). Wt1 is also specifically expressed in intermediate mesoderm mouse embryos at embryonic day (E)9.5 (Armstrong et al., 1993) and has an essential role in kidney development (Kreidberg et al., 1993). We found that the expression of both Osr1 and Wt1 was up-regulated in the differentiated cells treated with RA under most conditions (except for Osr1 expression with RA treatment from $5^{\text {th }}$ day) compared with undifferentiated mESCs and differentiated cells without RA (Fig. 1B, C). Osr1 expression was highest in the cells treated with RA from $3^{\text {rd }}$ day. Wt1 expression were comparable in the cells treated with RA from $2^{\text {nd }}$ and $3^{\text {rd }}$ day (Fig. 1B). Thus, we treated the cells with RA from $3^{\text {rd }}$ day in the following experiments. Next, we examined the expression level of Osr1 and Wt1 in the

Fig. 1. Time- and concentration-dependent effects of retinoic acid (RA) on the induction of intermediate mesodermal marker gene expression in differentiated mouse embryonic stem cells (ESCs). (A) Schematic representation of the experimental conditions. (B,C) Quantitative RT-PCR analysis of Osr1 and Wt1 mRNA levels in Activin A- and RAinduced mESCs cultured with $10 \mathrm{ng} / \mathrm{m} /$ of Activin $A$ (from $0^{\text {th }}$ day) and $0.1 \mu \mathrm{M}$ of RA (from each day as indicated in the graph) in ESF5 medium for 6 days. (D,E) Quantitative RT-PCR analysis of Osr1 and Wt1 mRNA levels in Activin A- and RA-induced $\mathrm{mESCs}$ cultured with $10 \mathrm{ng} / \mathrm{ml}$ of Activin A (from $0^{\text {th }}$ day) and various concentrations of $R A$ (from $3^{\text {rd }}$ day; concentration as indicated) in ESF5 medium for 6 days. The gene expression of each sample was normalized against the Gapdh mRNA level. The relative amount of the undifferentiated mESCS (ES) is indicated as 1.0. Values are mean $m$ SEM $(n=4)$. 
A
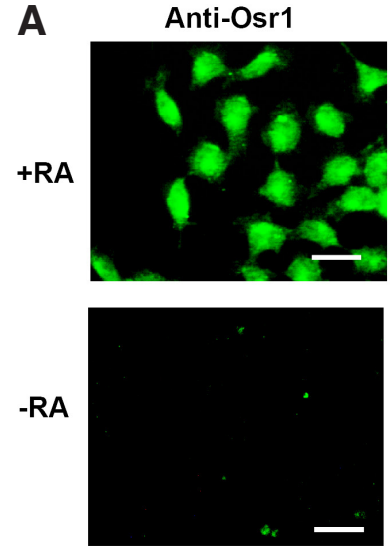

B
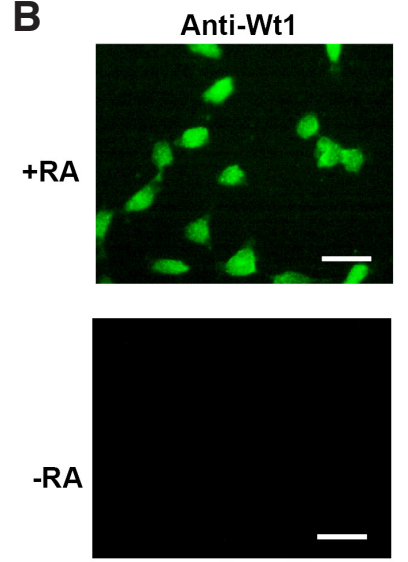

DAPI
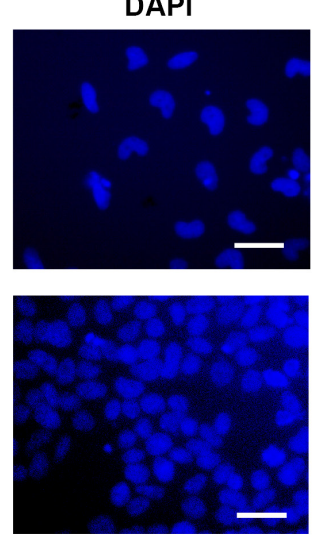

DAPI
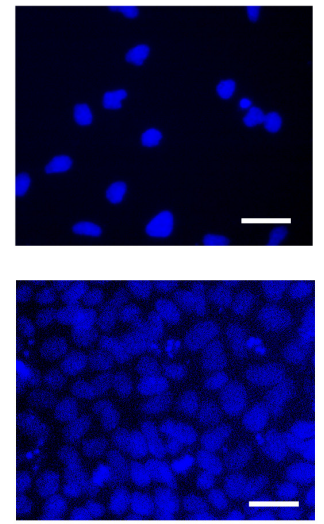
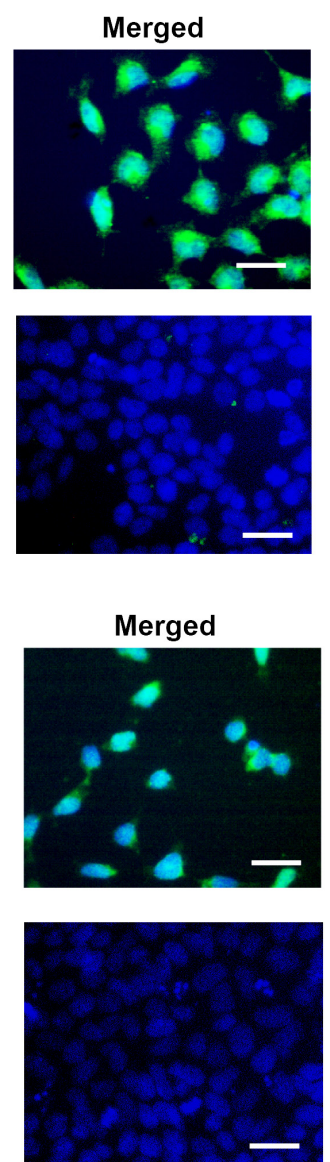

Fig. 2. Osr1 and Wt1 protein expression in differentiated mESCs treated with Activin A and retinoic acid (RA) by immunocytochemistry. Immunostaining for Osr1 and Wt1 in cells cultured with or without $0.1 \mu \mathrm{M}$ of RA (from $3^{\text {rd }}$ day) for 6 days. Immunoreactivity of Osr1 and Wt1 was visualized with Alexafluor 488-conjugated second antibodies (green). Nuclei were stained with DAPI (blue). Scale bars indicate $40 \mu \mathrm{m}$.

conditions with different RAconcentrations by quantitative RT-PCR. The mRNA level of Osr1 was up-regulated dose-dependently in the RA-treated cells and was highest with $100 \mathrm{nM}$ of RA treatment (Fig. 1D). The mRNA level of Wt1 was also up-regulated dose-dependently in the RA-treated cells and was highest with 100 or $1,000 \mathrm{nM}$ of RA treatment (Fig. 1E). Thus, we used 100 $\mathrm{nM}$ of RA for all subsequent experiments. These results indicate that RA treatment of the appropriate timing and concentration increased Osr1 and Wt1 expression following Activin A treatment in differentiating mESCs.

Next, we examined the protein expression of Osr1 and Wt1 in the differentiated cells cultured for 6 days with or without RA treatment in these culture conditions by immunocytochemistry. Many RA-treated cells were positively stained with Osr1- and Wt1-specific antibodies while untreated cells were negatively stained with these antibodies (Fig. 2A, B). These results indicated that RA treatment induced the protein expression of intermediate mesoderm in the differentiating mESCs.

Next, we examined the time course of the marker gene expression of undifferentiated mESCs, epiblast, and undifferentiated mesoderm during the induction into intermediate mesoderm. We determined the expression level of Oct4 as an undifferentiated mESC marker (Okamoto et al., 1990; Scholer et al., 1990), Fgf5

as an epiblast marker (Rathjen et al., 1999), and Brachyury $(T)$ as an undifferentiated mesodermal marker (Wilkinson et al., 1990) by quantitative RTPCR. Oct4 expression was down-regulated from $3^{\text {rd }}$ day onward, suggesting that differentiation from pluripotent state occurred in these culture conditions (Fig. 3A). Fgf5 expression was transiently up-regulated from $2^{\text {nd }}$ to $4^{\text {th }}$ day of induction, suggesting that the cells differentiated via epiblast state (Fig. 3B). Brachyury expression was up-regulated throughout the induction with a peak at $3^{\text {rd }}$ day of induction, suggesting that the cells also differentiated via primitive mesodermal state (Fig. $3 \mathrm{C}$ ). These results confirmed that the addition of RA following Activin $A$ in these culture conditions induces the step-wise mesodermal gene expression program from undifferentiated mESCs.

Differentiation potential of RA-induced cells using an ex vivo transplantation system

We asked whether the differentiated cells induced by RA following Activin A had the differentiation potential for kidney cells, we transplanted the cells into developing kidney ex vivo. RA-induced differentiated cells transduced with green fluorescent protein (GFP) by retroviral infection were injected into developing whole kidney isolated from mouse E12.5 and cultured for 5 days. Cryosections of the transplanted kidney were then immunostained for laminin and Pax2 protein expression. Laminin is expressed in the basement membrane of tubule structures in the developing kidney (Ekblom et al., 1980). Pax2 is expressed in collecting duct, metanephric mesenchyme and tubules derived from metanephric mesenchyme (Torres et al., 1995). Some of the GFP-expressing transplanted cells co-expressed laminin (Fig. 4A) or Pax2 (Fig. 4B) in the cryosections of cultured kidney explants. In addition, there were no teratoma-like structures observed in the explants (data not shown), suggesting mESCs were fully differentiated from the pluripotent stage. These results indicated that the transplanted cells were successfully integrated into the tubule structures and mesenchyme of a developing kidney and that the differentiated cells treated with RA following Activin A had the differentiation potential for kidney cells.

\section{Induction of intermediate mesoderm from mESCs by retinoic derivatives}

We asked how RA induced intermediate mesoderm from differentiating mESCs. RA generally regulates cell signaling and gene expression through binding to the RA receptors (RAR) or retinoid $X$ receptors (RXR) (Altucci et al., 2007). Since $R A$ can act as a ligand for both RAR and RXR, it is difficult to distinguish between the receptor signaling pathways. To examine which receptor signaling pathway is involved in the induction of intermediate mesoderm from mESCs, we used a pan RAR agonist, TTNPB (Afonja et al., 2002; Lu et al., 2008), and a pan RXR agonist, PA024 (Honda et al., 2005; Ishida et al., 2003; Takahashi et al., 2002), to mimic the effect of RA in our culture conditions. We detected the 
A
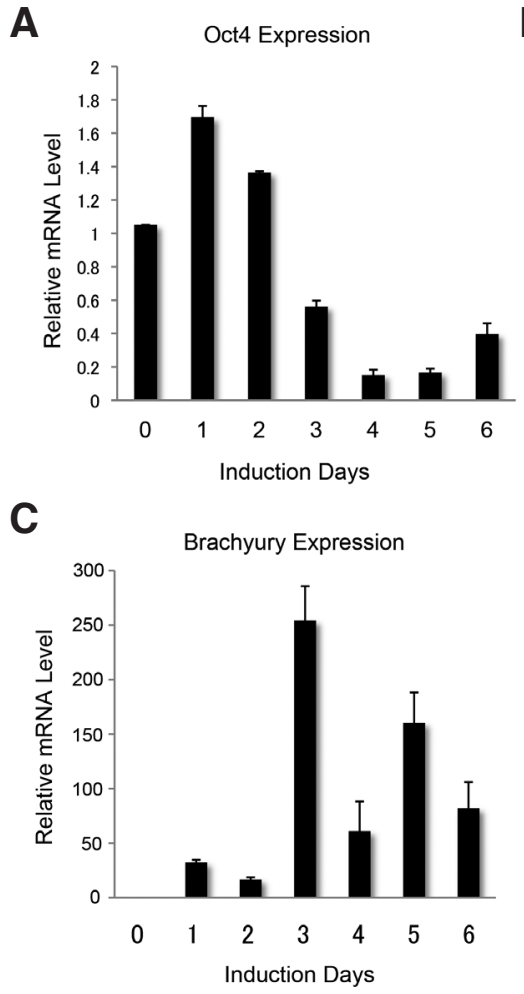

Fig. 3. The time course of differentiation marker expression in the differentiating mESCs treated with Activin A and retinoic acid (RA). Quantitative RT-PCR analyses of mRNA levels of Oct4 (A), Fgf5 (B), and Brachyury (C) in the differentiated mESCs treated with Activin A and RA. Cells cultured with $10 \mathrm{ng} / \mathrm{ml}$ of Activin A (from $0^{\text {th }}$ day) and $0.1 \mu \mathrm{M}$ of $R A$ (from $3^{\text {rd }}$ day) were collected at $O^{\text {th }}-6^{\text {th }}$ day. The gene expression of each sample was normalized against the Gapdh mRNA level. The amount of the undifferentiated mESCs $\left(0^{\text {th }}\right.$ day) is indicated as 1.0. Values are mean SEM $(\mathrm{n}=4)$. or without LE135. LE135 decreased their expression level induced by RA dose-dependently (Fig. 6A, B). These results indicated that RAR signaling was crucial for the $\mathrm{RA}$-induced differentiation of mESCs into intermediate mesoderm.

\section{Discussion}

In this study, we demonstrated that treating undifferentiated $\mathrm{mESCs}$ with RA following Activin A induced intermediate mesoderm. Under these defined culture conditions, both mRNA and proteins expressions of Osr1 and Wt1 were induced by RA addition. We also showed that the differentiated cells transplanted into developing kidney ex vivo were integrated into tubule structures marked by Laminin and renal epithelium marked by Pax2. Thus, these results suggested that the differentiated mESCs induced by RA and ActivinA can differentiate into renal lineages. Previous studies using embryoid bodies, which were formed from mESC aggregates, showed that mESCs could differentiate into renal lineages (Bruce et al., 2007; Vigneau et al., 2007); however, directed differentiation into renal lineage has been proven difficult to achieve due to the methods used. Although embryoid body differentiation methods are useful and convenient for differentiation into many cell types (Desbaillets et al., 2000; Keller, 1995), this method allows ESCs to differentiate in a random manner influenced by cell-cell contact and cell-autonomous secreted signals in the embryoid bodies. Moreover, these culture methods usually use serum or serum replacement, which include many unknown cytokines to affect cell differentiation. These influences are minimized in our culture method using serum- and feeder-free defined monolayer culture conditions, whereby known chemicals and cytokines are expression level of intermediate mesodermal markers, Osr1 and Wt1, in the differentiated mESCs treated with different concentrations of TTNPB or PA024 by quantitative RT-PCR. While PA024 at any concentration had no effect on the expression of either Osr1 or Wt1, TTNPB up-regulated both of their expression level dose-dependently (Fig. 5A, B). These results suggested that RAR signaling pathway was involved in the induction of intermediate mesoderm from mESCs.

To confirm the involvement of RAR signaling pathway in the induction of intermediate mesoderm from mESCs, we used an RAR antagonist, LE135 (Umemiya et al., 1997), together with RA. We detected the expression level of intermediate mesodermal markers, Osr1 and Wt1 in the differentiated mESCs treated with
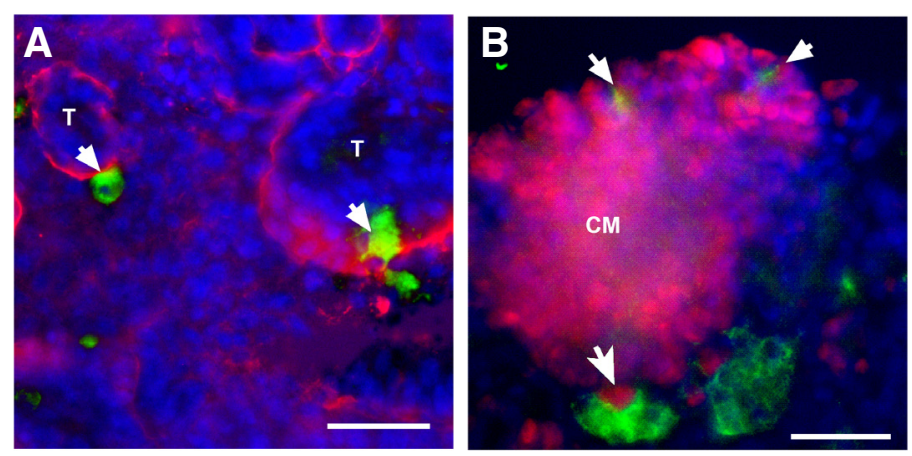
used to control cell fate decisions more precisely.

We have identified that RA is crucial for the induction of intermediate mesoderm using mESCs differentiation models. Generally, RA has pleiotropic effects in mESC differentiation and mammalian development (Clagett-Dame and DeLuca, 2002; Mark et al., 2006). In undifferentiated mESCs, RA inhibits their self-renewal and promotes their neurogenesis (Glaser and Brustle, 2005; Rohwedel et al., 1999). On the other hand, under our culture conditions, Activin A was used to induce mesendoderm from mESCs before RA is applied (Johansson and Wiles, 1995; Kubo et al., 2004), confirmed by the up-regulation of early mesodermal marker, Brachyury. Furthermore, treatment with Activin A prior to RA was needed to up-regulated the expression of Osr1 and Wt1. Thus, our results

Fig. 4. The contribution of differentiated mESCS treated with Activin $A$ and Retinoic acid (RA) to developing kidney ex vivo. Immunohist chemistry for GFP, Pax2, and laminin expression in cryosections of cultured whole kidney containing GFP-positive transplanted cells. Differentiated, GFP-transduced mESCs cells cultured in ESF5 medium with $10 \mathrm{ng} / \mathrm{ml}$ Activin A (from $0^{\text {th }}$ day) and $0.1 \mu M R A$ (from $3^{\text {rd }}$ day) for 6 days were transplanted into cultured whole kidney collected from mouse embryos at E12.5. Immunoreactivity of GFP was visualized with Alexafluor 488-conjugated secondary antibodies (green). Immunoreactivity of laminin (A) and Pax2 (B) was visualized with Alexafluor 594-conjugated second antibodies (red). Nuclei were stained with DAPI (blue). Arrows indicate cells double positive for GFP and differentiation markers. T, tubules; CM, condensed mesenchyme. Scale bars, $50 \mu \mathrm{m}$. 
suggested that RA directed intermediate mesoderm from primitive mesoderm. This step-wise, directed differentiation approach allows us to dissect the role of RA in mESC differentiation program and mammalian development.

We have also identified that RAR signaling pathway was involved in the differentiation into intermediate mesoderm. An RAR agonist specifically up-regulated the expression of intermediate mesodermal markers. Conversely, an RAR antagonist inhibited the RA-induced marker genes expression. These findings are consistent with the expression pattern of RAR and the phenotype of the RAR-deficient mice. RAR $\gamma$ begins to express in the posterior region of the embryo at E8.0 (Ruberte et al., 1990). Mice deficient in RAR $\alpha$ and RAR $\beta 2$ genes or RAR $\gamma$ impair renal development (Lohnes et al., 1993; Mendelsohn et al., 1999). Thus, our findings established an in vitro model to demonstrate the role of RAR signaling pathway in intermediate mesodermal induction using a mESC differentiation system. Our previous study show that RXR is involved in heart development using mESC differentiation system (Honda et al., 2005), suggesting that downstream signaling pathways of RA may differ among the mesodermal tissue formation.

In conclusion, this study demonstrated that sequential addition

A

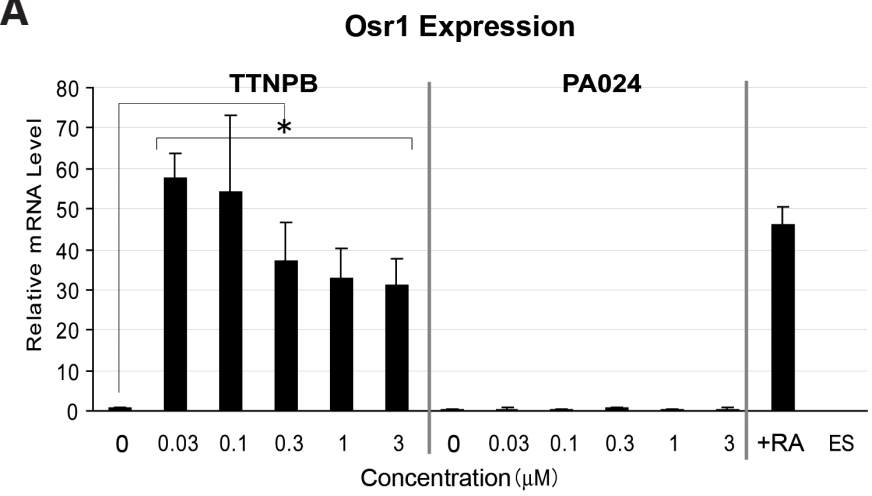

B

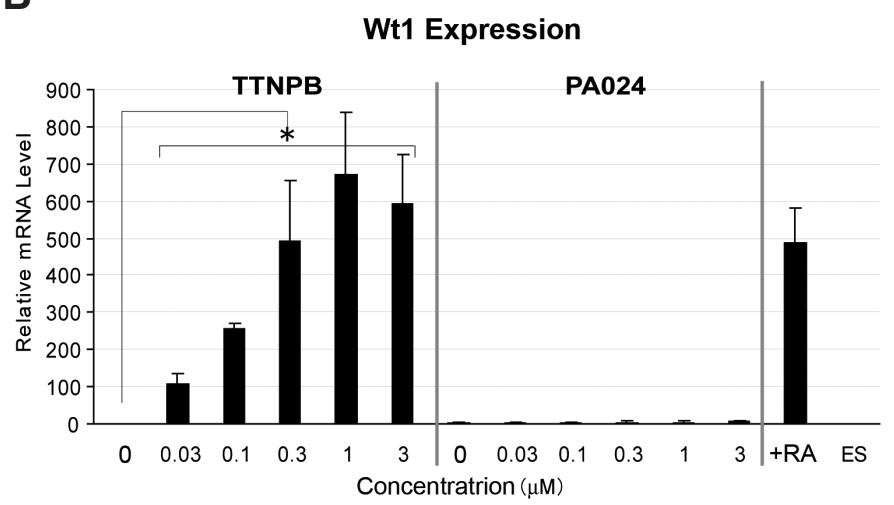

Fig. 5. The effect of retinoic acid receptor (RAR) and retinoid $X$ receptor (RXR) agonists on intermediate mesodermal marker expression. Quantitative RT-PCR analyses of Osr1 (A) and Wt1 (B) mRNA levels in the differentiated $m E S C S$, treated with Activin A and retinoic derivatives. The cells were cultured with $10 \mathrm{ng} / \mathrm{m}$ Activin A (from $0^{\text {th }}$ day) and various concentrations of an RAR agonist, TTNPB, or an RXR agonist, PAO24 (from $3^{r d}$ day) for 6 days. The gene expression of each sample was normalized against the Gapdh mRNA level. The amount of differentiated mESCs without $R A$ is indicated as 1.0. The values are mean SEM $(n=4)$.
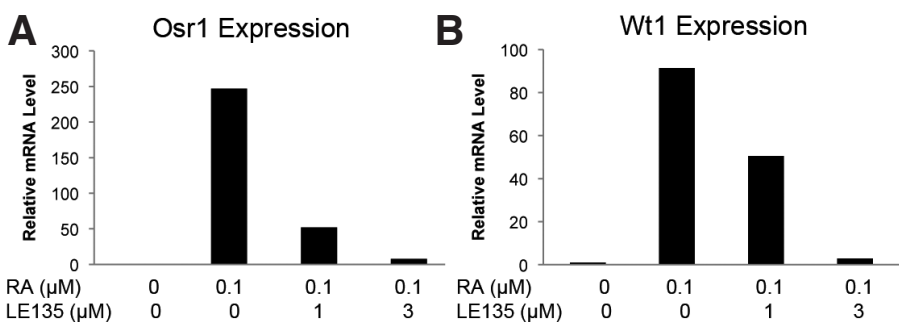

Fig. 6. The effect of a retinoic acid receptor (RAR) antagonist on intermediate mesodermal marker expression. Quantitative RT-PCR analyses of Osr1 (A) and Wt1 (B) mRNA levels in the differentiated mESCs, treated with Activin $A$ and RA with or without an RAR antagonist, LE135. The cells cultured with $10 \mathrm{ng} / \mathrm{m} /$ of Activin $A$ (from $0^{\text {th }}$ day) and various concentrations of LE135 with $0.1 \mu \mathrm{M}$ of RA (from $3^{r d}$ day) for 6 days. The gene expression of each sample was normalized against the Gapdh mRNA level. The amount of differentiated mESCs without RA is indicated as 1.0. Values are mean.

of Activin A and RA induced intermediate mesoderm from mESCs. Together with our previous studies using amphibian pluripotent (animal cap) cells (Moriya et al., 1993; Osafune et al., 2002; Uochi and Asashima, 1996), our findings imply that the induction of renal lineages by Activin A and RA is conserved among vertebrates. Therefore, we also expect that these findings will be applied to human pluripotent stem cells (Takahashi et al., 2007; Thomson et al., 1998; Yu et al., 2007). Since stem cells in the mature human mature kidney remain elusive (Yokoo et al., 2008), the differentiation into renal lineages from human PSCs could be useful for the realization of regenerative medicine of the kidney and successful drug development for renal diseases.

\section{Materials and Methods}

\section{Cell culture}

The mESC D3 (ATCC, CRL1934) line was routinely cultured as described previously (Furue et al., 2005; Hayashi et al., 2007). Briefly, the mESCs were cultured in $75-\mathrm{cm}^{2}$ plastic flasks (Corning), coated with 15 $\mu \mathrm{g} / \mathrm{ml}$ of type I collagen (Nitta gelatin), in a humidified atmosphere of $5 \%$ $\mathrm{CO}_{2}$ at $37^{\circ} \mathrm{C}$ in a defined ESF7 medium. The ESF7 consisted of ESF basal medium (Cell Science \& Technology Institute) supplemented with $10 \mu \mathrm{g} / \mathrm{ml}$ insulin, $5 \mu \mathrm{g} / \mathrm{ml}$ transferrin, $10 \mu \mathrm{M}$ 2-mercaptoethanol, $10 \mu \mathrm{M}$ 2-ethanolamine, $20 \mathrm{nM}$ sodium selenite, $9.4 \mu \mathrm{g} / \mathrm{ml}$ oleic acid conjugated with $2 \mathrm{mg} / \mathrm{ml}$ fatty acid-free bovine serum albumin (FAF-BSA; Sigma), and $10 \mathrm{ng} / \mathrm{ml}$ of leukemia inhibitory factor (LIF; Chemicon). For the differentiation experiments, mESCs were seeded at a density of $1 \times 10^{4} \mathrm{cells} / \mathrm{cm}^{2}$ in ESF5 medium, which comprised ESF basal medium supplemented with $10 \mu \mathrm{g} / \mathrm{ml}$ insulin, $5 \mu \mathrm{g} / \mathrm{ml}$ transferrin, $10 \mu \mathrm{M}$ 2-mercaptoethanol, $10 \mu \mathrm{M}$ 2-ethanolamine, $20 \mathrm{nM}$ sodium selenite added with $0.5 \mathrm{mg} / \mathrm{ml} \mathrm{FAF-BSA}$, and $10 \mathrm{ng} / \mathrm{ml}$ human recombinant Activin A (Ajinomoto pharmaceuticals), on $2 \mu \mathrm{g} / \mathrm{cm}^{2}$ laminin-coated (Sigma) dishes. The medium was changed every day. After the indicated days of culture under differentiating conditions, retinoid derivatives, or $0.02 \%$ dimethyl sulfoxide (DMSO, Sigma) as a solvent control were added in the medium. The preparation of these chemical solutions was described previously (Honda et al., 2005). Briefly, the RA (Sigma), RAR agonist (TTNPB; Sigma), RXR agonist (PA024, gifted from Dr. Kagechika (Takahashi et al., 2002)), and RAR antagonist (LE135, gifted from Dr. Kagechika (Takahashi et al., 2002)) were dissolved in DMSO to a stock concentration of $1 \mathrm{mM}$. The reagents were then filtered through a $0.22-\mu \mathrm{m}$ membrane filter (Millex-LG, Millipore), and aliquots were stored at $-20{ }^{\circ} \mathrm{C}$. The concentrations of retinoid derivatives in each experiment are indicated in the Results section. Stock retinoid derivatives solution was diluted with DMSO (Sigma). 


\section{$R T-P C R$}

RT-PCR was performed as described previously (Furue et al., 2005; Hayashi et al., 2007). Briefly, total RNA was extracted from the cultured cells using the total RNA extraction kit (Agilent) and reverse transcribed using Quantitect RT kit (Qiagen). Quantitative real-time PCR was performed with SYBR Green PCR Master Mix according to the supplier's directions (Applied Biosystems) using an ABI Step One Plus sequence detector (Applied Biosystems). Relative mRNA expression of each sample was normalized against Gapdh expression. The primer sequences are as follows: Gapdh (FW: 5'-ACCCAGAAGACTGTGGATGG-3', RV: 5'- CACATTGGGGGTAGGAACAC-3'), Brachyury (FW: 5'-TACCCCAGCCCCTATGCTCA-3', RV: 5'-GGCACTCCGAGGCTAGACCA-3'), Fgf5 (FW: 5'-GCTGTGTCTCAGGGGATTGT-3', RV: 5'-CACTCTCGGCCTGTCTTTTC-3'), Oct4 (FW: 5'-TTCTGCGGAGGGATGGCATA-3', RV: 5'-TTTCCACTCGTGCTCCTGCC-3'), Osr1 (FW: 5'- GACCGCGGCGGAACAAGATA-3', RV: 5'- CACTGTGGGCAGGCCATTCA-3'), Wt1 (FW: 5'-GCAACCACGGCACAGGGTAT-3', RV: 5'- GGGGCCACTCCAGATACACG-3'). All the results are expressed as the mean values with standard error $(n=4)$.

\section{Immunostaining}

Immunocytochemistry was performed as described previously (Furue et al., 2005; Hayashi et al., 2010a; Hayashi et al., 2007). Briefly, mESCs were fixed in $4 \%(\mathrm{w} / \mathrm{v})$ paraformaldehyde before being permealized with $0.1 \%$ Triton X-100, and then reacted with primary antibodies. The bound primary antibodies were visualized with AlexaFluor 488-conjugated anti-rabbit, antimouse, or anti-goat IgG or AlexaFluor 594-conjugated donkey anti-mouse, anti-rabbit, or anti-goat IgG (Invitrogen). The following primary antibodies were used: anti-Osr1 antibody (sc-68392 from Santa Cruz Biotechnology; 1:100), anti-Wt1 antibody (sc-192 from Santa Cruz Biotechnology; 1:100). anti-Pax2 antibody (covance; $10 \mu \mathrm{g} / \mathrm{ml}$ ), anti-laminin antibody (Sigma; 8 $\mu \mathrm{g} / \mathrm{ml}$ ), and anti-GFP antibody (Abcam; 1:200).

Transplantation of differentiated mESCs into developing kidneyex vivo

The developing kidneys of E12.5 embryos were collected from pregnant mice (C57BL/6JJcl, CLEA Japan) and cultured in DMEM + 10\% FCS on the culture filter. Differentiating mESCs were infected with retrovirus (concentrated) carrying GFP on $5^{\text {th }}$ day of induction. Retrovirus was concentrated from the culture medium of Plat-E cells (Cell Biolab) transfected with pMXs-GFP for 48 hours. At $6^{\text {th }}$ day of induction, GFP-transduced, differentiated mESCs (10,000 cells / explant) were injected into cultured whole kidney by microinjection using mouth pipettes. After 5 days of ex vivo culture, the cultured kidney were fixed with $4 \% \mathrm{PFA}$ in $4^{\circ} \mathrm{C}$ for $30 \mathrm{~min}$. Fixed samples were cryopreserved in OCT compound using the sucrose substitution method. Cryopreserved sections were cut at $13 \mu \mathrm{m}$ using a cryostat-microtome and used for immunostaining.

\section{Acknowledgements}

We would like to thank $H$. Kagechika for generously providing retinoic derivatives. This study was supported by the following funding: Grants-inaid for scientific research from the Ministry of Education, Culture, Sports, Science and Technology of Japan to M.A.; Grants from Wako pure chemical industries, Ltd. to M.A.; Grants-in-aid for scientific research from the Japan Society for the Promotion of Science to Y.H. and M. T.

\section{References}

AFONJA, O., RAAKA, B.M., HUANG, A., DAS, S., ZHAO, X., HELMER, E., JUSTE, D., AND SAMUELS, H.H. (2002). RAR agonists stimulate SOX9 gene expression in breast cancer cell lines: evidence for a role in retinoid-mediated growth inhibition. Oncogene 21: 7850-7860.

AIHARA, Y., HAYASHI, Y., HIRATA, M., ARIKI, N., SHIBATA, S., NAGOSHI, N., NAKANISHI, M., OHNUMA, K., WARASHINA, M., MICHIUE, T., et al., (2010). Induction of neural crest cells from mouse embryonic stem cells in a serum-free monolayer culture. Int J Dev Biol 54: 1287-1294.

ALTUCCI, L., LEIBOWITZ, M.D., OGILVIE, K.M., DE LERA, A.R., AND GRONE-
MEYER, H. (2007). RAR and RXR modulation in cancer and metabolic disease. Nat Rev Drug Discov 6: 793-810.

ARIIZUMI, T., AND ASASHIMA, M. (2001). In vitro induction systems for analyses of amphibian organogenesis and body patterning. Int J Dev Biol 45: 273-279.

ARMSTRONG, J.F., PRITCHARD-JONES, K., BICKMORE, W.A., HASTIE, N.D., AND BARD, J.B. (1993). The expression of the Wilms' tumour gene, WT1, in the developing mammalian embryo. Mech Dev 40: 85-97.

ASASHIMA, M., NAKANO, H., SHIMADA, K., KINOSHITA, K., ISHII, K., SHIBAI, H. UENO, N. (1990). Mesodermal induction in early amphibian embryos by activin A (erythroid differentiation factor). Roux's Arch Dev Biol 198: 330-335.

ASASHIMA, M., NAKANO, H., UCHIYAMA, H., SUGINO, H., NAKAMURA, T., ETO, Y., EJIMA, D., NISHIMATSU, S., UENO, N., AND KINOSHITA, K. (1991). Presence of activin (erythroid differentiation factor) in unfertilized eggs and blastulae of Xenopus laevis. Proc Natl Acad Sci USA 88: 6511-6514.

BRUCE, S.J., REA, R.W., STEPTOE, A.L., BUSSLINGER, M., BERTRAM, J.F., AND PERKINS, A.C. (2007). In vitro differentiation of murine embryonic stem cells toward a renal lineage. Differentiation 75: 337-349.

CLAGETT-DAME, M., AND DELUCA, H.F. (2002). The role of vitamin Ain mammalian reproduction and embryonic development. Annu Rev Nutr 22: 347-381.

DESBAILlETS, I., ZIEGLER, U., GROSCURTH, P., AND GASSMANN, M. (2000). Embryoid bodies: an in vitro model of mouse embryogenesis. Exp Physiol 85: 645-651.

DRESSLER, G.R. (2009). Advances in early kidney specification, development and patterning. Development 136: 3863-3874.

DUESTER, G. (2008). Retinoic acid synthesis and signaling during early organogenesis. Cell 134: 921-931.

EKBLOM, P., ALITALO, K., VAHERI, A., TIMPL, R., AND SAXEN, L. (1980). Induction of a basement membrane glycoprotein in embryonic kidney: possible role of laminin in morphogenesis. Proc Natl Acad Sci USA 77: 485-489.

EVANS, M.J., AND KAUFMAN, M.H. (1981). Establishment in culture of pluripotential cells from mouse embryos. Nature 292: 154-156.

FUKUI, A., AND ASASHIMA, M. (1994). Control of cell differentiation and morphogenesis in amphibian development. Int J Dev Biol 38: 257-266.

FURUE, M., OKAMOTO, T., HAYASHI, Y., OKOCHI, H., FUJIMOTO, M., MYOISHI, Y., ABE, T., OHNUMA, K., SATO, G.H., ASASHIMA, M., et al., (2005). Leukemia inhibitory factor as an anti-apoptotic mitogen for pluripotent mouse embryonic stem cells in a serum-free medium without feeder cells. In vitro Cell Dev Biol Anim 41: 19-28.

GLASER, T., AND BRUSTLE, O. (2005). Retinoic acid induction of ES-cell-derived neurons: the radial glia connection. Trends Neurosci 28: 397-400.

GOUMANS, M.J., AND MUMMERY, C. (2000). Functional analysis of the TGFbeta receptor/Smad pathway through gene ablation in mice. Int J Dev Bio/44: 253-265.

HAYASHI, Y., CHAN, T., WARASHINA, M., FUKUDA, M., ARIIZUMI, T., OKABAYASHI, K., TAKAYAMA, N., OTSU, M., ETO, K., FURUE, M.K., et al., (2010a). Reduction of $\mathrm{N}$-glycolylneuraminic acid in human induced pluripotent stem cells generated or cultured under feeder- and serum-free defined conditions. PLoS One 5: e14099.

HAYASHI, Y., FURUE, M.K., OKAMOTO, T., OHNUMA, K., MYOISHI, Y., FUKUHARA Y., ABE, T., SATO, J.D., HATA, R., AND ASASHIMA, M. (2007). Integrins regulate mouse embryonic stem cell self-renewal. Stem Cells 25: 3005-3015.

HAYASHI, Y., FURUE, M.K., TANAKA, S., HIROSE, M., WAKISAKA, N., DANNO, H., OHNUMA, K., OEDA, S., AIHARA, Y., SHIOTA, K., et al., (2010b). BMP4 induction of trophoblast from mouse embryonic stem cells in defined culture conditions on laminin. In vitro Cell Dev Biol Anim 46: 416-430.

HONDA, M., HAMAZAKI, T.S., KOMAZAKI, S., KAGECHIKA, H., SHUDO, K., AND ASASHIMA, M. (2005). RXRagonistenhances the differentiation of cardiomyocytes derived from embryonic stem cells in serum-free conditions. Biochem Biophys Res Commun 333: 1334-1340.

ISHIDA, S., SHIGEMOTO-MOGAMI, Y., KAGECHIKA, H., SHUDO, K., OZAWA, S., SAWADA, J., OHNO, Y., AND INOUE, K. (2003). Clinically potential subclasses of retinoid synergists revealed by gene expression profiling. Mol Cancer Ther2: 49-58.

JOHANSSON, B.M., AND WILES, M.V. (1995). Evidence for involvement of activin A and bone morphogenetic protein 4 in mammalian mesoderm and hematopoietic development. Mol Cell Biol 15: 141-151.

KANEKO, K., SATO, K., MICHIUE, T., OKABAYASHI, K., OHNUMA, K., DANNO, H., AND ASASHIMA, M. (2008). Developmental potential for morphogenesis in vivo 
and in vitro. J Exp Zool B Mol Dev Evol 310: 492-503.

KELLER, G.M. (1995). In-Vitro Differentiation of Embryonic Stem-Cells. Curr Opin Cell Biol 7: 862-869.

KREIDBERG, J.A., SARIOLA, H., LORING, J.M., MAEDA, M., PELletieR, J., HOUSMAN, D., AND JAENISCH, R. (1993). WT-1 is required for early kidney development. Cell 74: 679-691.

KUBO, A., SHINOZAKI, K., SHANNON, J.M., KOUSKOFF, V., KENNEDY, M., WOO, S., FEHLING, H.J., AND KELLER, G. (2004). Development of definitive endoderm from embryonic stem cells in culture. Development 131: 1651-1662.

LOHNES, D., KASTNER, P., DIERICH, A., MARK, M., LEMEUR, M., AND CHAMBON, P. (1993). Function of retinoic acid receptor gamma in the mouse. Cell73:643-658.

LU, Y., BRATTON, S., HEYDEL, J.M., AND RADOMINSKA-PANDYA, A. (2008). Effect of retinoids on UDP-glucuronosyltransferase 2B7 mRNA expression in Caco-2 cells. Drug Metab Pharmacokinet 23: 364-372.

MARK, M., GHYSELINCK, N.B., AND CHAMBON, P. (2006). Function of retinoid nuclear receptors: lessons from genetic and pharmacological dissections of the retinoic acid signaling pathway during mouse embryogenesis. Annu Rev Pharmacol Toxicol 46: 451-480.

MARTIN, G.R. (1981). Isolation of a pluripotent cell line from early mouse embryos cultured in medium conditioned by teratocarcinoma stem cells. Proc Natl Acad Sci USA 78: 7634-7638.

MENDELSOHN, C., BATOURINA, E., FUNG, S., GILBERT, T., AND DODD, J. (1999). Stromal cells mediate retinoid-dependent functions essential for renal development. Development 126: 1139-1148.

MORIYA, N., UCHIYAMA, H., AND ASASHIMA, M. (1993). Induction of Pronephric Tubules by Activin and retinoic Acid in Presumptive Ectoderm of Xenopus laevis. Develop Growth \& Differ 35: 123-128.

NAKANISHI, M., KURISAKI, A., HAYASHI, Y., WARASHINA, M., ISHIURA, S., KUSUDA-FURUE, M., AND ASASHIMA, M. (2009). Directed induction of anterior and posterior primitive streak by Wnt from embryonic stem cells cultured in a chemically defined serum-free medium. FASEB J 23: 114-122.

NISHINAKAMURA, R. (2008). Stem cells in the embryonic kidney. Kidney Int 73: 913-917.

OKABAYASHI, K., AND ASASHIMA, M. (2003). Tissue generation from amphibian animal caps. Curr Opin Genet Dev 13: 502-507.

OKAMOTO, K., OKAZAWA, H., OKUDA, A., SAKAI, M., MURAMATSU, M., AND HAMADA, H. (1990). A novel octamer binding transcription factor is differentially expressed in mouse embryonic cells. Cell 60: 461-472.

OSAFUNE, K., NISHINAKAMURA, R., KOMAZAKI, S., AND ASASHIMA, M. (2002). In vitro induction of the pronephric duct in Xenopus explants. Dev Growth Differ 44: 161-167.

RATHJEN, J., LAKE, J.A., BETTESS, M.D., WASHINGTON, J.M., CHAPMAN, G., AND RATHJEN, P.D. (1999). Formation of a primitive ectoderm like cell population, EPL cells, from ES cells in response to biologically derived factors. J Cell Sci 112: 601-612.

REIDY, K.J., AND ROSENBLUM, N.D. (2009). Cell and molecular biology of kidney development. Semin Nephrol 29: 321-337.

ROHWEDEL, J., GUAN, K., AND WOBUS, A.M. (1999). Induction of cellular differentiation by retinoic acid in vitro. Cells Tissues Organs 165: 190-202.

RUBERTE, E., DOLLE, P., KRUST, A., ZELENT, A., MORRISS-KAY, G., AND CHAMBON, P. (1990). Specific spatial and temporal distribution of retinoic acid receptor gamma transcripts during mouse embryogenesis. Development 108: 213-222.

SCHIER, A.F., AND SHEN, M.M. (2000). Nodal signalling in vertebrate development. Nature 403: 385-389.

SCHOLER, H.R., RUPPERT, S., SUZUKI, N., CHOWDHURY, K., AND GRUSS, P. (1990). New type of POU domain in germ line-specific protein Oct-4. Nature 344: 435-439.

TAKAHASHI, B., OHTA, K., KAWACHI, E., FUKASAWA, H., HASHIMOTO, Y., AND KAGECHIKA, H. (2002). Novel retinoid X receptor antagonists: specific inhibition of retinoid synergism in RXR-RAR heterodimer actions. J Med Chem 45: 3327-3330.

TAKAHASHI, K., TANABE, K., OHNUKI, M., NARITA, M., ICHISAKA, T., TOMODA K., AND YAMANAKA, S. (2007). Induction of pluripotent stem cells from adult human fibroblasts by defined factors. Cell 131: 861-872.

TAKAHASHI, K., AND YAMANAKA, S. (2006). Induction of pluripotent stem cells from mouse embryonic and adult fibroblast cultures by defined factors. Cell126:663-676.

THOMSON, J.A., ITSKOVITZ-ELDOR, J., SHAPIRO, S.S., WAKNITZ, M.A., SWIERGIEL, J.J., MARSHALL, V.S., AND JONES, J.M. (1998). Embryonic stem cell lines derived from human blastocysts. Science 282: 1145-1147.

TORRES, M., GOMEZ-PARDO, E., DRESSLER, G.R., AND GRUSS, P. (1995). Pax-2 controls multiple steps of urogenital development. Development 121: 4057-4065.

UMEMIYA, H., FUKASAWA, H., EBISAWA, M., EYROLLES, L., KAWACHI, E., EISENMANN, G., GRONEMEYER, H., HASHIMOTO, Y., SHUDO, K., AND KAGECHIKA, H. (1997). Regulation of retinoidal actions by diazepinylbenzoic acids. Retinoid synergists which activate the RXR-RAR heterodimers. J Med Chem 40: 4222-4234.

UOCHI, T., AND ASASHIMA, M. (1996). Sequential gene expression during pronephric tubule formation in vitro in zenopus ectoderm. Develop Growth \& Differ38:614-634

VIGNEAU, C., POLGAR, K., STRIKER, G., ELLIOTT, J., HYINK, D., WEBER, O., FEHLING, H.J., KELLER, G., BURROW, C., AND WILSON, P. (2007). Mouse embryonic stem cell-derived embryoid bodies generate progenitors that integrate long term into renal proximal tubules in vivo. J Am Soc Nephrol 18: 1709-1720.

WANG, Q., LAN, Y., CHO, E.S., MALTBY, K.M., AND JIANG, R. (2005). Odd-skipped related 1 (Odd 1 ) is an essential regulator of heart and urogenital development. Dev Biol 288: 582-594.

WILKINSON, D.G., BHATT, S., AND HERRMANN, B.G. (1990). Expression pattern of the mouse $T$ gene and its role in mesoderm formation. Nature 343: 657-659.

YOKOO, T., KAWAMURA, T., AND KOBAYASHI, E. (2008). Stem cells for kidney repair: useful tool for acute renal failure? Kidney Int 74: 847-849,

YU, J., VODYANIK, M.A., SMUGA-OTTO, K., ANTOSIEWICZ-BOURGET, J., FRANE, J.L., TIAN, S., NIE, J., JONSDOTTIR, G.A., RUOTTI, V., STEWART, R., et al., (2007). Induced pluripotent stem cell lines derived from human somatic cells. Science 318: 1917-1920. 


\section{Further Related Reading, published previously in the Int. J. Dev. Biol.}

Retinoic acid stability in stem cell cultures

Kyle A. Sharow, Boris Temkin and Mary Ann Asson-Batres

Int. J. Dev. Biol. (2012) 56: 273-278

Expression analysis of the polypyrimidine tract binding protein (PTBP1) and its paralogs PTBP2 and PTBP3 during Xenopus tropicalis embryogenesis

Maud Noiret, Yann Audic and Serge Hardy

Int. J. Dev. Biol. (2012) 56: 747-753

Induction of neural crest cells from mouse embryonic stem cells in a serum-free monolayer culture

Yuko Aihara, Yohei Hayashi, Mitsuhi Hirata, Nobutaka Ariki, Shinsuke Shibata, Narihito Nagoshi, Mio Nakanishi, Kiyoshi Ohnuma, Masaki Warashina, Tatsuo Michiue, Hideho Uchiyama, Hideyuki Okano, Makoto Asashima and Miho Kusuda Furue Int. J. Dev. Biol. (2010) 54: 1287-1294

Revisiting old vaginal topics: conversion of the Müllerian vagina and origin of the "sinus" vagina Yi Cai

Int. J. Dev. Biol. (2009) 53: 925-934

Limb muscle development

Bodo Christ and Beate Brand-Saberi

Int. J. Dev. Biol. (2002) 46: 905-914

In vitro induction systems for analyses of amphibian organogenesis and body patterning.

T Ariizumi and M Asashima

Int. J. Dev. Biol. (2001) 45: 273-279

Mesonephric kidney--a stem cell factory?

K Sainio and A Raatikainen-Ahokas

Int. J. Dev. Biol. (1999) 43: 435-439

Towards a molecular anatomy of the Xenopus pronephric kidney

A W Brändli

Int. J. Dev. Biol. (1999) 43: 381-395

Control of cell differentiation and morphogenesis in amphibian development.

A Fukui and M Asashima

Int. J. Dev. Biol. (1994) 38: 257-266

5 yr ISI Impact Factor $(2011)=2.959$
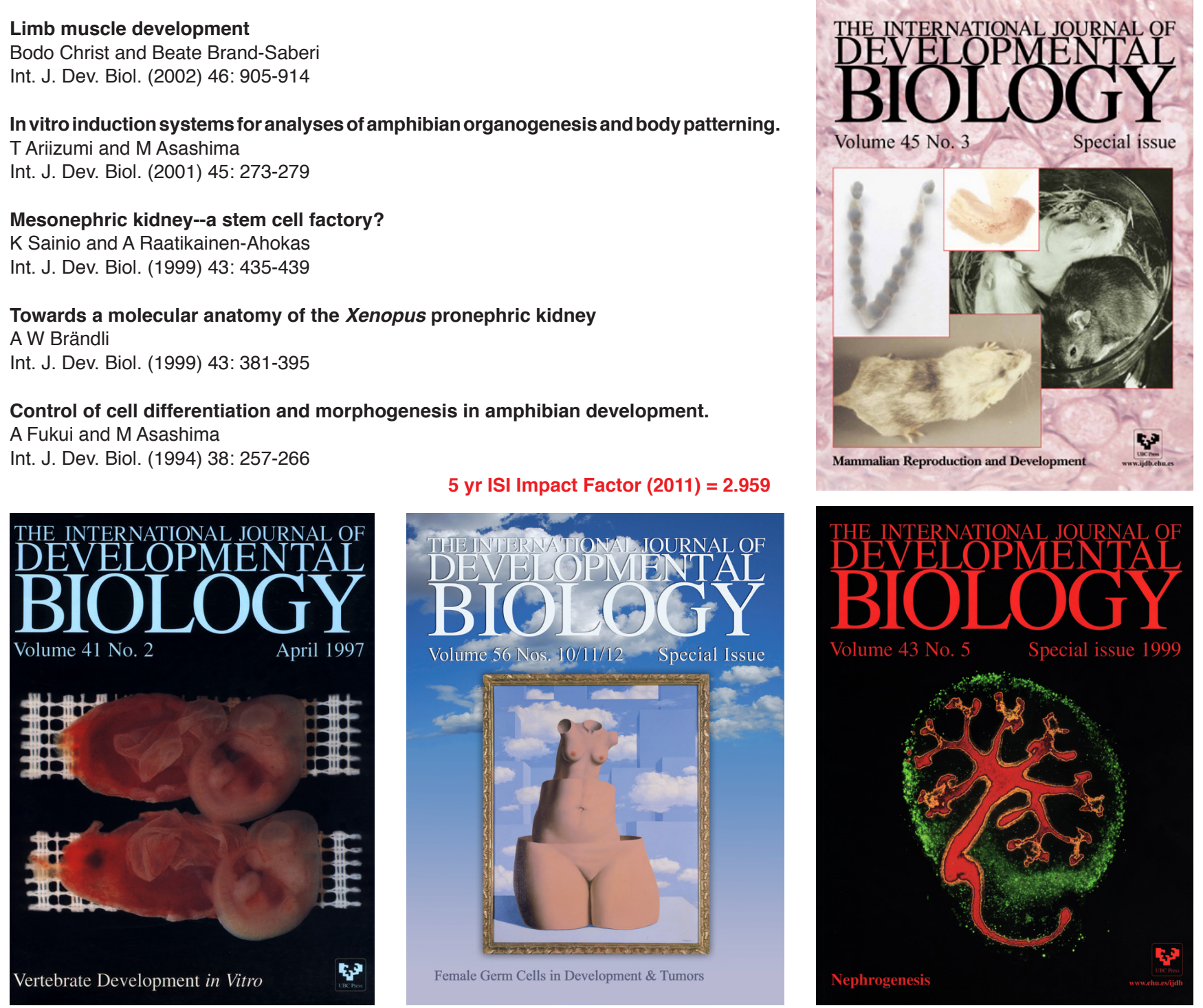